The final publication is available at Elsevier via http://dx.doi.org/10.1016/j.jamda.2017.05.003 @ 2017. This manuscript version is made available under the CC-BY-NC-ND 4.0 license http://creativecommons.org/licenses/by-nc-nd/4.0/

\title{
Prevalence and determinants of poor food intake of residents living in long- term care
}

Heather H Keller PhD RD ${ }^{1}$ (corresponding author), Natalie Carrier, $\mathrm{PhD}, \mathrm{RD}^{2}$, Susan E. Slaughter PhD, $\mathrm{RN}^{3}$, Christina Lengyel PhD, $\mathrm{RD}^{4}$, Catriona M Steele PhD SLP ${ }^{5,6}$, Lisa Duizer, $\mathrm{PhD}^{7}$, Jill Morrison $\mathrm{MSc}^{8}$, K. Stephen Brown $\mathrm{PhD}^{9}$, Habib Chaudhury $\mathrm{PhD}^{10}$, Minn N Yoon, Phd ${ }^{11}$, Alison M. Duncan PhD, $\mathrm{RD}^{12}$, Veronique Boscart, RN, $\mathrm{PhD}^{13}$, George Heckman MD, MSc, FRCPC ${ }^{1}$, Lita Villalon, PhD, FDC, RD ${ }^{2}$

${ }^{1}$ Schlegel-University of Waterloo Research Institute for Aging, 250 Laurelwood Drive, Waterloo, ON N2J 0E2 Canada hkeller@uwaterloo.ca; ggheckma@uwaterloo.ca ; ${ }^{2} E$ cole des sciences des aliments, de nutrition et d'études familiales, Faculté des sciences de la santé et des services communautaires, Université de Moncton, Moncton, NB E1A 3E9 Canada Natalie.carrier@umoncton.ca; Lita.villalon@umoncton.ca; ${ }^{3}$ Faculty of Nursing, University of Alberta, Edmonton, Alberta T6G 1C9 Canada Susan.slaughter@ualberta.ca; ${ }^{4}$ Faculty of Agricultural \& Food Sciences, University of Manitoba, Winnipeg, MB R3T 2N2 Canada christina.lengyel@umanitoba.ca; ${ }^{5}$ Toronto Rehabilitation Institute, University Health Network, 550 University Avenue, \#12-101, Toronto, Ontario, Canada M5G 2A2 Rehabilitation Sciences Institute, Faculty of Medicine; ${ }^{6}$ University of Toronto, Toronto, ON M5G 1V7 Canada Catriona.steele@uhn.ca; ${ }^{7}$ Department of Food Science, University of Guelph, Guelph, ON N1G 2W1 Canada 1duizer@uoguelph.ca; Department of Kinesiology, University of Waterloo, Waterloo, ON N2L 3G1 Canada, jill.morrison@uwaterloo.ca; ${ }^{9}$ Department of Statistics and Actuarial Science, University of Waterloo, Waterloo Ontario N2L 3G1Canada ksbrown@uwaterloo.ca; ${ }^{10}$ Department of Gerontology, Simon Fraser University, 2800-515 W. Hastings St., Vancouver, BC Canada V6B 5K3 chaudhury@sfu.ca, ${ }^{11}$ School of Dentistry, 5-575, Edmonton Clinic Health Academy,11405-87 Avenue, University of Alberta, Edmonton, AB T6G 1C9 minn.yoon@ualberta.ca; ${ }^{12}$ Department of Human Health and Nutritional Sciences, University of Guelph, Guelph, ON N1G 2W1 Canada amduncan@,uoguelph.ca; ${ }^{13}$ Conestoga College, School of Health Sciences and Community Services, 299 Doon Valley Drive, Kitchener, Ontario, N2G 4M4 Canada vboscart@,conestogac.on.ca 


\begin{abstract}
Objective: Poor food intake is known to lead to malnutrition in long-term care (LTCH), yet multi-level determinants of food intake are not fully understood, hampering development of interventions that can maintain nutritional status of residents. This study measures energy and protein intake of LTCH residents, describes prevalence of diverse covariates, and the association of covariates with food intake.

Design: Multi-site cross-sectional study.

Setting: 32 nursing homes from four provinces in Canada.

Participants: From a sample of 639 residents (20 randomly selected per home), 628 with complete data included in analyses.

Measurements: Three days of weighed food intake (main plate, estimated
\end{abstract} beverages and side dishes, snacks) were completed to measure energy and protein intake. Health records were reviewed for diagnoses, medications, and diet prescription. Mini-Nutritional Assessment-SF was used to determine nutritional risk. Oral health and dysphagia risk were assessed with standardized protocols. The Edinburgh-Feeding Questionnaire (Ed-FED) was used to identify eating challenges; Mealtime interactions with staff were assessed with the Mealtime Relational Care Checklist. Mealtime observations recorded duration of meals and assistance received. Dining environments were assessed for physical features using the Dining Environment Audit Protocol and the Mealtime Scan was used to record mealtime experience and ambiance. Staff completed the Person Directed Care questionnaire and managers completed a survey describing features of the home and foodservices. Hierarchical multivariate regression determined predictors of energy and protein intake adjusted for other covariates.

Results: Average age of participants was $86.3 \pm 7.8$ years and $69 \%$ were female. Median energy intake was $1571.9 \pm 411.93$ kilocalories and protein $58.4 \pm 18.02$ $\mathrm{g} /$ day. There was a significant interaction between being prescribed a pureed/liquidized diet and eating challenges for energy intake. Age, number of eating challenges, pureed/liquidized diet, and sometimes requiring eating assistance were negatively associated with energy and protein intake. Being male, a higher Mini-Nutritional Assessment-Short Form score, often requiring eating assistance, and being on a dementia care unit were positively associated with energy and protein intake. Energy intake alone was negatively associated with homelikeness scores but positively associated with person-centred care practices, while protein intake was positively associated with more dietitian time.

Conclusion: This is the first study to consider resident, unit, staff and home variables that are associated with food intake. Findings indicate that interventions focused on pureed food, restorative dining, eating assistance and person-centered care practices may support improved food intake and should be the target for further research.

Keywords: food intake, long-term care, determinants, nutrition, person-centered care 


\section{Introduction}

Poor food intake and subsequent malnutrition are pervasive among older adults living in long term care homes (LTCHs) (1-5). Weight loss and poor nutritional status of these elders have been implicated in falls, chronic wounds, poor wound healing, hospital admission, disproportionate use of health services, and reduced quality of life (6-10). Poor food intake is the primary mechanism for malnutrition in this population and is potentially preventable for some residents $(4,11)$. To better understand how to improve food intake among these elders, we first need to understand what resident, home, and staff characteristics are most prevalent and associated with food intake. Prior work based on small sample sizes has resulted in limited understanding of the prevalence of various risk factors and which modifiable variables are relevant. A comprehensive assessment of factors and how they are associated with food intake is absent in the literature. The Making the Most of Mealtimes (M3) conceptual model suggests three domains of: 1) meal access (e.g., dysphagia, self-feeding capacity), 2) meal quality (e.g., nutrient density, sensory appeal), and 3) mealtime experience (e.g., ambiance) that can influence food intake in residential settings. This model notes that all of these domains can be influenced by resident (e.g., diagnosis of dementia), staff (e.g., number, skill), home (e.g., policy, philosophy of care) and regional factors (e.g., regulation) (12). This conceptual model demonstrates how complex food intake can be in LTCHs, but also provides a map for further understanding these complex relationships.

To date, research on determinants of food intake in residential environments has focused on only one or two levels of influence (e.g. home, resident) (13); few key 
factors, often not modifiable (e.g., dementia, eating difficulties) $(14,15)$; or data from relatively few residents and/or homes $(4,6)$. Furthermore, few studies have rigorously measured food intake (4) or considered the cluster effect of units within homes, and residents within units, when determining associations (13). This study was designed to overcome these limitations and will: 1) describe energy and protein intake (as proxies of total and quality food intake respectively) and prevalence of a comprehensive list of resident, unit and home covariates and 2) identify the factors associated with total energy and protein intake in a large, diverse sample of LTCH residents when adjusted for other covariates.

\section{Methods}

Subjects \& Setting: The complete protocol for this cross-sectional, multi-site study is described in detail elsewhere (16). In brief, 32 purposively selected LTCHs from four Canadian provinces participated. Two to three units within each home were randomly selected (dementia care unit included if available) for recruitment. With the assistance of a trained home staff member, residents were randomly selected and recruited to reach a quota of 20 residents per home. Eligible residents were $\geq 65$ years of age, provided (or alternate decision-maker [ADM]) informed consent and were medically stable (no hospital admission in previous month or palliative), had been in the home for at least one month, ate an oral diet, and typically ate in the dining room. The home staff member approached the resident/ADM to determine interest in learning more about the study. Research staff obtained informed consent to participate. 
Research Staff: Provincial research leads in each province are experts in dietetics/nutrition or nursing with extensive experience in the conduct of research in LTCHs; they provided study oversight and quality control in each province. A coordinator (background in dietetics/nutrition, three were practicing dietitians) was responsible for all data collection within each home in their province and dayto-day management of the project. Provincial research leads and coordinators attended an in-person, three-day training session for all procedures, including practicing of all data collection measures to promote standardization. Provincial coordinators and research leads trained two further research assistants (post baccalaureate health studies/nutrition) in their province for meal observations (e.g. length of meal, observation of eating behaviors/challenges), food intake assessment and nutrient analysis. A dental hygienist for each province was contracted to complete the standardized oral health exams; they were trained by a co-investigator with this expertise. Monthly teleconferences were completed throughout the study to address data collection issues and further promote consistency in measurement and procedures.

Food Intake: Three nonconsecutive days of weighed food intake (before and after consumption of items on main plate and estimated beverages, side dishes and snacks), were collected for each resident. Food Processor Nutrition Analysis Software version 10.14.1 (ESHA Research, Salem, OR, USA) was used with home recipes to estimate intake; average intake of energy and protein were dependent variables for this analysis. A detailed procedure (16) was followed to promote accuracy in assessment of food intake and nutrient analysis. Specifically, home 
recipes were used to complete the nutrient analysis concurrently with data collection to provide opportunity for clarification with the home staff. Research assistants checked each other's work, and rules were followed with respect to food substitution for nutrient analysis when a recipe was unavailable (16). The Canadian Nutrient File was used for foods/ingredients where fortification practices would influence nutrient content.

Resident Covariates: Resident variables (e.g., medication, use of supplements, diet prescription, 6-month weight history) were collected from the health record by the provincial coordinator. Modified food texture diets were classified for analysis using the International Dysphagia Diet Standardisation Initiative (IDDSI) as there were a wide variety of modified food texture labels used by homes (17). Descriptions of food products that were consumed were used to make this categorization for individual diet prescription (e.g. minced meat became 'minced \& moist' IDDSI category 5). Mini-nutritional assessment short form (MNA-SF) was completed based on health record information and discussion with staff/family/resident. Patient-Gênerated Subjective Global Assessment (18) was used to diagnose malnutrition; only the ratings of A (well nourished), B (mild/moderate malnutrition) and C (severe malnutrition) were used in the analyses. Ulna length was used to estimate height (19) and calculate Body Mass Index. Provincial coordinators interviewed staff to complete items on the interRAILTCHF 2.0 to determine cognitive performance, depression, pain and activities of daily living (20-25). Experienced and research-trained dental hygienists assessed oral health by using a standardized oral health exam (26). Dysphagia risk was 
defined as either 1) the resident was prescribed thickened fluids, 2) they failed a standardized swallowing challenge using water and applesauce (27), or 3) they coughed or choked during meal observations when food and fluid intake were collected. Finally, during one meal on each day of observation, eating behaviors and interactions between staff and residents were also documented using the Edinburgh Feeding Questionnaire (Ed-FED) (28) plus nine further eating challenges (e.g., coughing, choking, playing with food) that were similarly scored and summarized into an Other Eating Challenges score; the Relational Behavior Scale for those requiring total eating assistance (29), and the Mealtime Relational Care Checklist (30). Duration of every meal was measured and mealtime behaviors observed were averaged to provide a single score/value per resident for analysis.

Staff and Setting Covariates: A site survey was completed by home management and explored food delivery and preparation, menu planning/variety (score based on number of unique items per day and week), clinical dietitian time, raw food (i.e. amount of money spent solely on food) and oral nutritional supplement cost and other home (e.g. profit status) and unit (e.g. number of beds) variables. Staff (minimum of 10 per home) completed the Person Directed Care questionnaire (31). Provincial coordinators completed the Mealtime Scan (MTS) (30) and Dining Environment Audit Protocol (32) to determine person-centered care practices, physical and social rating of observed meals and homelikeness and functionality of the dining rooms (maximum rating 8 for all summary scales). The number of residents and staff in the dining room, excess noise and use of music during meals was also captured with the MTS, which was completed four to six 
times for each dining room. Ethical approval was provided by review boards at the Universities of Alberta, Guelph, Manitoba, Moncton, Toronto, and Waterloo.

Statistical Analyses: Descriptive analyses were completed for key resident and site covariates (Table 1). Multivariate hierarchical linear regression was used to consider this nested design (residents in units in homes in provinces) when examining the significance of factors associated with energy and protein intake. The intraclass correlation (ICC) values of each of the four levels of nesting were calculated to determine the proportion of variance in food intake that was accounted for by each nested level prior to inclusion of potential covariates. Covariates hypothesized from the M3 conceptual model to be associated with intake were included in the analysis; those statistically associated at $\mathrm{p}<0.25$ are provided in Table 2. Energy and protein intake were regressed on each variable of interest, while adjusting for age and gender (Table 3). The unexplained variation between homes and units within homes was used to assess covariates at the home and unit levels respectively. All variables with coefficients significant at $p<0.25$ were included in a backward regression analysis, which was reduced one variable at a time, based on the least significant coefficient (i.e., with the greatest p-value), starting with resident-level variables, followed by unit- and then home-level variables. Where variables were collinear, the initial full model was developed with only one covariate (e.g. MNA-SF and PG-SGA; Dietitian hours per week vs. > 0.5 FTE etc.). This process continued until all coefficients in the model were significant at $\mathrm{p}<0.05$. Potential interactions between covariates were also tested. $R^{2}$ values were used to determine the most parsimonious model and post-hoc tests were performed 
to identify outliers, potential collinearity and goodness of fit. All analyses were performed using SAS® 9.4 statistical software (SAS Institute Inc., Cary, North Carolina).

\section{Results}

Descriptive data for resident and homes are provided in Table 1 (Supplementary tables 1-3 provide further detail). The mean age of the residents was $86.8 \pm 7.8$ years and $69 \%$ were female. Median energy intake (unadjusted for individual variation) was $1571.9 \pm 411.9$ kilocalories/day $(\mathrm{kcal} / \mathrm{d})$ and protein 58.4 \pm 18.0 grams/day (g/d); however less than $50 \%$ had low protein intake using the

Dietary Reference Intake of $0.8 \mathrm{~g} / \mathrm{kg}$ bodyweight/day. Using PG-SGA, 44\% of participants were malnourished (B/C categories) and the most common diagnosis was dementia (65\%; supplementary table 1). Residents were highly vulnerable; almost a quarter required eating assistance, almost $50 \%$ had poor oral health that would affect food intake and a similar proportion were on modified-texture diets. Almost a third of participants were in dementia care units and all dining rooms assessed had moderate ratings for homelikeness and functionality. Mealtimes had moderate scores for person-centeredness, social and physical environments that supported the mealtime experience and ambiance. Registered dietitians were present in all homes, although there was considerable variation in their weekly availability. Menus were typically revised every six months, although more than 5\% of homes had not altered their menu in the past year.

A total of 11 residents were excluded from the bivariate and multivariate analyses $(n=628)$ due to limited $(<2$ days) food records $(n=6)$, eating in their rooms 
$(\mathrm{n}=4)$ missing a MNA-SF score $(\mathrm{n}=1)$. Bivariate analyses provided in Table 2 (meet criteria of $\mathrm{p}<0.25$; see supplementary tables for all variables analyzed) for both energy and protein demonstrated several potential covariates for inclusion in the initial multivariate models; negative values indicate that the covariate decreased energy or protein intake. As anticipated, some variables were only associated with protein intake which is considered a proxy for diet quality (e.g., number of drugs prescribed, number of teeth, use of thickened fluids, having cultural preferences met, biggest meal of the day, dietitian time, raw food cost etc.).

Table 3 provides the multivariate analysis. A significant interaction was found between pureed/liquidized diet type and eating challenges at meals for energy intake; thus, final models accounting for this interaction are used for interpretation and discussion. Age was negatively associated with energy and protein intake. For every one-year increase in age, energy declined by $9 \mathrm{kcal} / \mathrm{d}$ and protein intake declined by $0.39 \mathrm{~g} / \mathrm{d}$ when adjusted for other variables in the model. As anticipated, males had higher energy and protein intakes than females. There was a negative association between energy and protein intake and Ed-FED scores. A higher score on the Ed-FED indicates a greater number of eating challenges; for each one-point increase in this score there was a resulting decrease of $63 \mathrm{kcal} / \mathrm{d}$ and $3 \mathrm{~g} / \mathrm{d}$ of protein. In final models where the interaction between pureed/liquidized food texture and eating assistance was considered, there was a negative but non significant association between consuming a pureed/liquidized diet and energy and protein intake. MNA-SF was positively associated with energy and protein intake. For each one-point increase in MNA-SF, there was a $24 \mathrm{kcal} / \mathrm{d}$ and $0.65 \mathrm{~g} / \mathrm{d}$ protein 
increase. Those who often (or totally) required eating assistance according to the Ed-FED had higher energy and protein intake (positive association), whereas those who only occasionally received assistance had lower energy and protein intake (negative association) when compared with those who could eat by themselves or rarely required assistance. The interaction between texture and eating challenges was positive and significant for energy; plotting of the association revealed that a high proportion of residents requiring pureed texture also had eating challenges. The home dietitian being a 0.5 full-time equivalent or higher was positively associated with protein intake; those receiving this level of care had a $3.4 \mathrm{~g} / \mathrm{d}$ on average greater intake than those in homes with less clinical dietitian time. A higher homelikeness score was negatively associated with energy intake, however this effect was modest to nominal, decreasing intake by $20 \mathrm{kcal} / \mathrm{d}$ for each one-point change in score. Person-centred care ratings from the MTS were positively associated with energy intake; a one-point increase in this score resulted in an average $307 \mathrm{kcal} / \mathrm{d}$ increase. These two unit variables were not included in the final models for protein intake. Finally, living in a dementia care unit was positively associated with energy $(+148.5 \mathrm{kcal} / \mathrm{d})$ and protein $(+4.1 \mathrm{~g} / \mathrm{d})$ intake.

\section{Discussion}

This landmark study considers a comprehensive list of potential covariates affecting food intake at the resident, unit and home levels, in a large and diverse sample. Data were collected using rigorous methods primarily based on researcher measurement and observation. This is the first time that some variables, (e.g., mealtime relational care practices and dining room environment) have been studied 
with food intake. This research not only provides unique and important insights regarding the prevalence of diverse risk factors, but also identifies several potential root causes of poor food intake in LTCHs. It should be noted that some variables collected in the study were not described or modeled here, as they were only completed for residents with adequate cognition (e.g., food satisfaction, smell acuity). Future analyses will focus on these aspects of the M3 concept. The prevalence data alone are noteworthy and can be used for advocacy as well as planning of future investigations (see supplemental tables). Specifically, the composite dysphagia risk variable and modified-texture diet variables using the new International Dysphagia Diet Standardization Initiative classification, provide the best estimates to date in residential care. The identified high prevalence reinforces the importance of providing quality modified foods as well as managing dysphagia in LTCHs. Oral health data were collected based on a clinical examination rather than the typical approach of reviewing administrative data sets and provides evidence for challenges with respect to oral care and its impact on food intake. Both the objective and subjective ratings of oral health status of the study sample underscore the pressing need for quality oral care in LTCHs and future analyses will examine these issues. Prior studies of food intake in LTCHs demonstrating diet inadequacy are confirmed by our observations of relatively low and highly variable intake $(4,11,13)$. Future analyses will compare actual to recommended micronutrient intake to assess adequacy.

Bivariate and multivariate analyses have identified covariates relevant to food consumption. Although not significant in the final models, covariates 
significantly associated at the bivariate level should also be considered as potential areas for improving food intake. For example, more recent menu revisions $(<6$ months) were associated with higher protein and energy intake (Table 2) suggesting that this should be standard practice in LTCHs. The multivariate analyses conducted in this study confirm prior findings that pureed food $(34,35)$, eating challenges (36, 37), eating assistance (38), and malnutrition (37) are important determinants of food intake. However, prior work examining eating assistance has failed to differentiate if level of help provided (i.e., sometimes vs. often) is a relevant distinction. This analysis suggests that it is, and future work should continue to describe intake by level of assistance required rather than as a dichotomous variable. Prior work has also suggested a confounding relationship between eating assistance and modified texture food intake (35) and this study demonstrates the importance of considering this interaction in future research. These results could be interpreted as total eating assistance overcoming the deficit in food intake that is often seen with pureed food prescription. Certainly, there is a need for eating assistance interventions (e.g., volunteers), especially given projections regarding the increasing number of residents requiring total meal assistance. Yet, this study suggests that more attention should be paid to restorative techniques that support self-feeding and overcome eating challenges, while providing assistance when needed; close monitoring of intake is required to ensure that residents on the cusp of losing their eating ability do not decrease their intake. The significant effect of dementia care units and person-centered care practices suggests that how meals are provided to residents is important to overall consumption. Person-centered care 
practices at mealtimes involve showing respect and acknowledgement of the individual resident, treating each in a dignified manner and focusing on the individual's need, rather than the task, while building and sustaining social relationships $(39,40)$. Interventions targeting this aspect of mealtime are needed. This analysis also suggests that physical changes to promote 'homelikeness' are not sufficient to improve food intake.

Study Limitations: Although a rigorous and detailed data collection has provided new understanding on the complexity of factors associated with food intake, this study is not without some limitations. Random selection of homes was not feasible, but diversity of homes was attained with purposive sampling (16); thus, the homes and participants cannot be considered representative of Canadian LTCHs. However, comparison of randomly recruited participants to the eligible pool in the home demonstrated that participants were representative of their home (16). Several highly trained researchers were required due to the geographic distribution of the data collection. This likely introduced some bias in measurement, especially with respect to potentially subjective measures such as the DEAP and MTS summary scales, or measures with poorly defined categorizations (e.g. Ed-FED never/rarely vs. sometimes vs. often). Clustered hierarchical analysis was used to adjust for province and home effects, as reliability testing across assessors was infeasible. Further longitudinal analyses should be used to confirm novel associations identified in this cross-sectional study (e.g., sometimes vs. often requiring eating assistance, person-centred care practices). Further, some measures were not possible, because of the cognitive capacity of residents (e.g. chewing ability). Finally, 
MTSs were not necessarily completed at meals where food intake of participants was being assessed; it was assumed that four to six meal observations with this measure represented participants' mealtime experience. This could mean that associations between these dining room level variables and food intake are spurious. Future studies should conduct these measures concurrently with food intake of participants, now that key variables such as person-centred care at mealtimes have been shown to be relevant.

\section{Conclusions}

This is the first known study to assess a comprehensive list of risk factors that influence meal quality, mealtime experience and meal access in a large and diverse sample of residents in LTCHs in Canada. Longitudinal studies are recommended to confirm associations between some of the novel results such as levels of eating assistance, or person-centred care practices and energy and protein intake. Prevalence data from this study are especially useful for documenting the relative importance of key issues that can impact food intake for residents in long-term care. Practice implications from this research include inclusion of clinical oral health and dysphagia assessment in LTCHs; sufficient clinical dietitian time for menu planning, resident assessment and treatment; improving the quality of modified texture foods; and designing physical dining spaces that support person centred-care. Future intervention research should focus on developing and evaluating education programs for staff and family that support resident self-feeding, how to overcome eating challenges with restorative dining and graduated eating assistance, as well as person-centred care practices at mealtimes. Such interventions and improved care 
practices should also be studied longitudinally to demonstrate benefits with respect to key outcomes for residents, such as falls, hospitalizations and quality of life. 


\section{Ethics Approval and Consent to Participate}

All study participants or alternative decision makers for residents provided their written consent to participate. This protocol received clearance from ethics boards at the University of Waterloo, University of Alberta (Pro00050002), University of Manitoba (J2014:139), Université de Moncton (1415-022), and University Hospital Network, University of Toronto (16-5051-DE). Some individual LTCH homes also required ethics review by a local/regional committee.

\section{Acknowledgements}

The study would not have been possible without the expertise and dedication of project managers (Hilary Dunn, Carla Ickert), the provincial site coordinators, research assistants, the dental hygienists, and the interest and cooperation of participating homes, residents and families. We greatly appreciate their efforts and contributions to the M3 prevalence study.

\section{Conflict of Interest}

HK, VB, GH are all endowed research chairs affiliated with the Schlegel-University of Waterloo Research Institute for Aging. HK is on the speakers bureau for Fresenius Kabi, Nestlé Health Science, and Abbott Nutrition.

\section{Funding}

Canadian Institutes for Health Research provided peer-reviewed funding for this study [grant numbers 201403MOP-326892-NUT-CENA-25463].

\section{Authors' Contributions}


All authors reviewed and provided input specific to their expertise and experience for this manuscript and approved this manuscript. The Primary Investigator, HK, led the research team and data collection and developed the initial draft of this manuscript. Co-Principal investigators LD and CS provided their expertise to specific aspects of the methodology and participated in monthly calls during and post data collection to provide guidance. CoPrincipal investigators SES, CL, and NC led data collection within their province and supervised local research personnel. JM completed all analyses. Co-investigator KSB provided statistical consultation; VB, GH, AD, MY, HC, and LV provided expertise in protocol development specific to their areas of expertise. 


\section{References}

1. Cereda E, Pedrolli C, Klersy C, et al. Nutritional status in older persons according to healthcare setting: A systematic review and meta-analysis of prevalence data using MNA®. Clin Nutr 2016; 35:1281-1290.

2. López-Contreras MJ, López M, Canteras M, et al. Identification of different nutritional status groups in institutionalized elderly people by cluster analysis. Nutr Hosp 2014;29(3):602-610.

3. Gordon AL, Franklin M, Bradshaw L, et al. Health status of UK care home residents: a cohort study. Age Ageing 2014;43:97-103.

4. Aghdassi E, McArthur M, Liu B, et al. Dietary intake of elderly living in Toronto long-term care facilities: comparison to the dietary reference intake. Rejuvenation Res 2007;10(3):301-309.

5. Engelheart S, Akner G. Dietary intake of energy, nutrients and water in elderly people living at home or nursing home. J Nutr Health Aging. 2015;19(3):265-72.

6. Singh D KA, Manaf ZA, Muhammad NA, et al. Correlation between nutritional status and comprehensive physical performance measures among older adults with undernourishment in residential institutions. Clin Interventions Aging 2014;9:1415-1423.

7. Wirth R, Streicher M, Smoliner C, et al. The impact of weight loss and low BMI on mortality of nursing home residents- results from the nutritionDay in nursing homes. Clin Nutr 2016;35(4):900-906.

8. Neyens J, Halfens R, Spreeuwenberg M, et al. Malnutrition is associated with increased risk of falls and impaired activity in elderly patients in Dutch residential long-term care (LTC): A cross-sectional study. Arch Gerontol Geriatrics 2013;56:265-269.

9. Beck AM. Weight loss, mortality and associated potentially modifiable nutritional risk factors among nursing home residents- A Danish follow -up study. J Nutr Health Aging 2015;19(1): 96-101.

10. Kostka J, Borowiak E, Kostka T. Nutritional status and quality of life in different populations of older people in Poland. Eur J Clin Nutr 2014;68(11):1210-5.

11. Wendland BE, Greenwood CE, Weinberg I, et al. Malnutrition in institutionalized seniors: the iatrogenic component. J Am Geriatrics Soc 2003;51:85-90.

12. Keller H, Carrier N, Duizer L, et al. Making the Most of Mealtimes (M3): grounding mealtime interventions with a conceptual model. J Am Med Dir Assoc 2014;15(3):158-161.

13. Strathmann S, Lesser S, Bai-Habelski J, et al. Institutional factors associated with the nutritional status of residents from 10 German nursing homes (ERNSTES Study). J Nutr Health Aging 2013;17(3): 271-276

14. Verbrugghe M, Beeckman D, van Hecke A, et al. Malnutrition and associated factors in nursing home residents in Flanders, Belgium: A cross-sectional, multicentre study. Clin Nutr 2013;32(3):438-443.

15. Törma J, Winblad U, Cederholm T, et al. Does undernutrition still prevail among nursing home residents? Clin Nutr 2013;32(4):562-568.

16. Keller H, Carrier N, Slaughter S, et al. Making the Most of Mealtimes (M3): protocol of a multi-centre cross-sectional study of food intake and its 
determinants in older adults living in long term care homes. BMC Geriatrics 2017;17:15 DOI 10.1186/s12877-016-0401-4

17. Cichero JA, Lam P, Steele CM, et al. Development of International Terminology and Definitions for Texture-Modified Foods and Thickened Fluids Used in Dysphagia Management: The IDDSI Framework. Dysphagia 2016;Dec 2:1-22.

18. Bauer J, Capra S, Ferguson M. Use of the scored patient-generated subjective global assessment (PG-SGA) as a nutrition assessment tool in patients with cancer. Eur J Clin Nutr 2002; 56:779-785.

19. Todorovic V, Russell C, Elia M, for the Malnutrtion Action Group, British Association for Parenteral and Eneral Nutrtiion. The 'MUST' Explanatory Booklet. A guide to the 'Malnutrition Universal Screening Tool' ('MUST') for Adults. 2003 http://www.bapen.org.uk/pdfs/must/must explan.pdf. Accessed Jun $5,2014$.

20. Hirdes JP, Ljunggren G, Morris JN, et al. Reliability of the interRAI suite of assessment instruments: a 12 -country study of an integrated health information system. BMC Health Services Res 2008; 8:277 doi:10.1186/1472-6963-8-277.

21. Morris JN, Fries BE, Morris SA. Scaling ADLs within the MDS. J Gerontol: Med Sci 1999;54A(11):M546-53.

22. Koehler M, Rabinowitz T, Hirdes J, Stones M, Carpenter GI, Fires Be, Morris Jn, Jones RN. Measuring depression in nursing home residents with the MDS and GDS: An observational psychometric study. BMC Geriatrics. 2005, 5:

23. Morris JN, Fries BE, Mehr DR, et al. MDS Cognitive Performance Scale. J Gerontol: Med Sci 1994;49(4): M174-M182.

24. Smart KA, Hermann N, Lanctôt KL. Validity and responsiveness to change of clinically derived MDS scales in Alzheimer disease outcomes research. J Geriatric Psych Neurol 2011;24(2):67-72.

25. Fries BE, Simon SE, Morris JN, et al. Pain in U.S. nursing homes

26. Statistics Canada. Canadian Health Measures Survey - Cycle 2 - 2009-2011. Statistics Canada. http://www23.statcan.gc.ca/imdb/p2SV.pl?Function=getInstrumentLink\&SurvIte $\mathrm{m} I d=129548 \& Q u e r y \quad I d=62444 \& Q u e r y=$ instance $\&$ lang $=$ en $\& d b=i m d b \& a d m=8$ \&dis=2. (2012). Accessed November 23, 2012.

27. Shephard TJ, Kovach AM, Hale K, et al. STAND (Screening Tool for Acute Neurological Dysphagia) study results. American Association of Neuroscience Nurses Annual Meeting, San Diego, Ca, April, 2007.

28. Watson R, Deary IJ. Feeding difficulty in elderly patients with dementia: confirmatory factor analysis. International J Nurs Studies 1997;34:405-14.

29. McGilton KS, Sidani S, Boscart VM, et al. The relationship between care providers' relational behaviors and residents mood and behavior in long-term care settings. Aging Men Health 2012;16(4):507-15.

30. Keller HH, Chaudhury H, Pfisterer K, et al. Development and inter-rater reliability of the Mealtime Scan for long-term care. Gerontol 2017 (in press).

31. White DL, Newton-Curtis L, Lyons KS. Development and initial testing of a measure of person-directed care. Gerontol 2008;48(special issue 1):114-123. 
32. Chaudhury H, Keller H, Pfisterer K, et al. Development of a physical environmental observational tool for dining environments in long-term care settings. Gerontol 2017 (in press).

33. Kaiser MJ, Bauer JM, Ramsch C, et al. Validation of the Mini Nutritional Assessment short -form (MNA-SF): a practical tool for identification of nutritional status. J Nutr Health Aging 2009;13(90:782-8.

34. Dahl WJ, Whiting SJ, Tyler RT. Protein content of puréed diets: implications for planning. Can J Diet Prac Res 2007;68(2): 99-102

35. Keller H, Chambers L, Ferugsson DA, et al. A mix menu of bulk and ready to use modified-texture food: Impact on clinical weight goals, weight and meal plate intake among older persons requiring dysphagic food products. Can J Aging 2012;31(3):335-48.

36. Slaughter SE, Eliasziw M, Morgan D, et al. Incidence and predictors of eating disability among nursing home residents with middle-stage dementia. Clin Nutr 2011;30(2):172-77.

37. Tamura BK, Bell CL, Masaki KH, et al. Factors associated with weight loss, low BMI, and malnutrition among nursing home patients: A systematic review of the literature. J Am Med Dir Assoc 2013; doi:10.1016/j.jamda.2013.02.022

38. Simmons SF, Schnelle JF. Individualized feeding assistance care for nursing home residents: staffing requirements to implement two interventions. J Gerontol: Med Sci 2004;59A (9):966-73.

39. Ducak K, Sweatman, G, Keller H. Dining culture change in long-term care homes: Transitioning to resident-centered and relational meals. Ann Long Term Care: Clin Care Aging. 2015;23(6):28-36.

40. Reimer HD, Keller HH. Mealtimes in nursing homes: striving for person-centred care. J Nutr Elder 2009;28:327-347 
Table 1. Characteristics of total M3 sample $(n=639)$

\begin{tabular}{|c|c|}
\hline Characteristic & $\begin{array}{l}\text { Mean (SD)/ Frequency of } \\
\text { Characteristic (n of 639) }\end{array}$ \\
\hline \multicolumn{2}{|l|}{ Resident Level } \\
\hline Age (years) & $86.8( \pm 7.83)$ \\
\hline Gender, male & $31.1 \%(199)$ \\
\hline Energy Intake, kcal/day & $1571.9( \pm 411.93)$ \\
\hline Protein Intake, $\mathrm{g} /$ day & $58.4( \pm 18.02)$ \\
\hline$\leq 0.8 \mathrm{~g}$ protein $/ \mathrm{kg}$ bodyweight & $41.6 \%(266)$ \\
\hline BMI* & $25.3( \pm 5.75)$ \\
\hline Malnutrition (PG-SGA; $\mathrm{B}$ or $\mathrm{C}$ rating)* & $44.0 \%(281)$ \\
\hline MNA-SF Score* & $10.6( \pm 2.53)$ \\
\hline CHF diagnosis* & $12.8 \%(82)$ \\
\hline COPD diagnosis & $15.3 \%(98)$ \\
\hline Current cancer* & $15.0 \%(96)$ \\
\hline Depression Scale (InterRAI)* & $2.3( \pm 2.92)$ \\
\hline $\begin{array}{l}\text { Moderate/Severe Cognitive Impairment (InterRAI } \\
\text { CPS 3+) }\end{array}$ & $55.7 \%(353)$ \\
\hline ADL score (InterRAI)* & $15.0( \pm 7.86)$ \\
\hline Number of drugs prescribed & $7.5( \pm 7.00)$ \\
\hline Number of diagnoses & $5.4( \pm 2.03)$ \\
\hline \multicolumn{2}{|l|}{ Level of pain (InterRAI)* } \\
\hline None & $60.8 \%(386)$ \\
\hline Less than daily & $27.9 \%(177)$ \\
\hline Daily pain & $11.3 \%(72)$ \\
\hline Any oral pain* & $10.5 \%(45)$ \\
\hline Dysphagia risk & $59.2 \%(378)$ \\
\hline Irregular Saliva* & $38.7 \%(220)$ \\
\hline Number of teeth* & $9.5( \pm 10.15)$ \\
\hline Oral health status likely to affect food intake* & $49.4 \%(280)$ \\
\hline Poor denture fit* & $32.1 \%(179)$ \\
\hline Urgent dental care required* & $8.6 \%(49)$ \\
\hline Modified texture (IDDSI Levels 3-6) & $47.1 \%(301)$ \\
\hline Pureed/Liquidized (IDDSI Levels 3-4) & $11.1 \%(71)$ \\
\hline Thickened fluids (any) & $10.6 \%(68)$ \\
\hline Any diet prescription & $37.7 \%(241)$ \\
\hline Cultural preferences met & $70.4 \%(446)$ \\
\hline ONS prescribed & $30.7 \%(196)$ \\
\hline Ed-FED score* & $12.4( \pm 2.25)$ \\
\hline Other eating challenges score* & $10.6( \pm 1.65)$ \\
\hline \multicolumn{2}{|l|}{ Physical help required during mealtime* } \\
\hline Never & $76.8 \%(487)$ \\
\hline Sometimes & $11.4 \%(72)$ \\
\hline Often & $11.8 \%(75)$ \\
\hline Average mealtime length* & $40.2( \pm 13.04)$ \\
\hline Positive:Negative M-RCC Score* & $2.2( \pm 1.32)$ \\
\hline \multicolumn{2}{|l|}{ Unit-level } \\
\hline Dementia care unit (yes) & $28.8 \%(184)$ \\
\hline Renovations to unit in past 5 years* & $20.2 \%(127)$ \\
\hline DEAP Functionality of dining room (max 8) & $5.3( \pm 1.03)$ \\
\hline
\end{tabular}




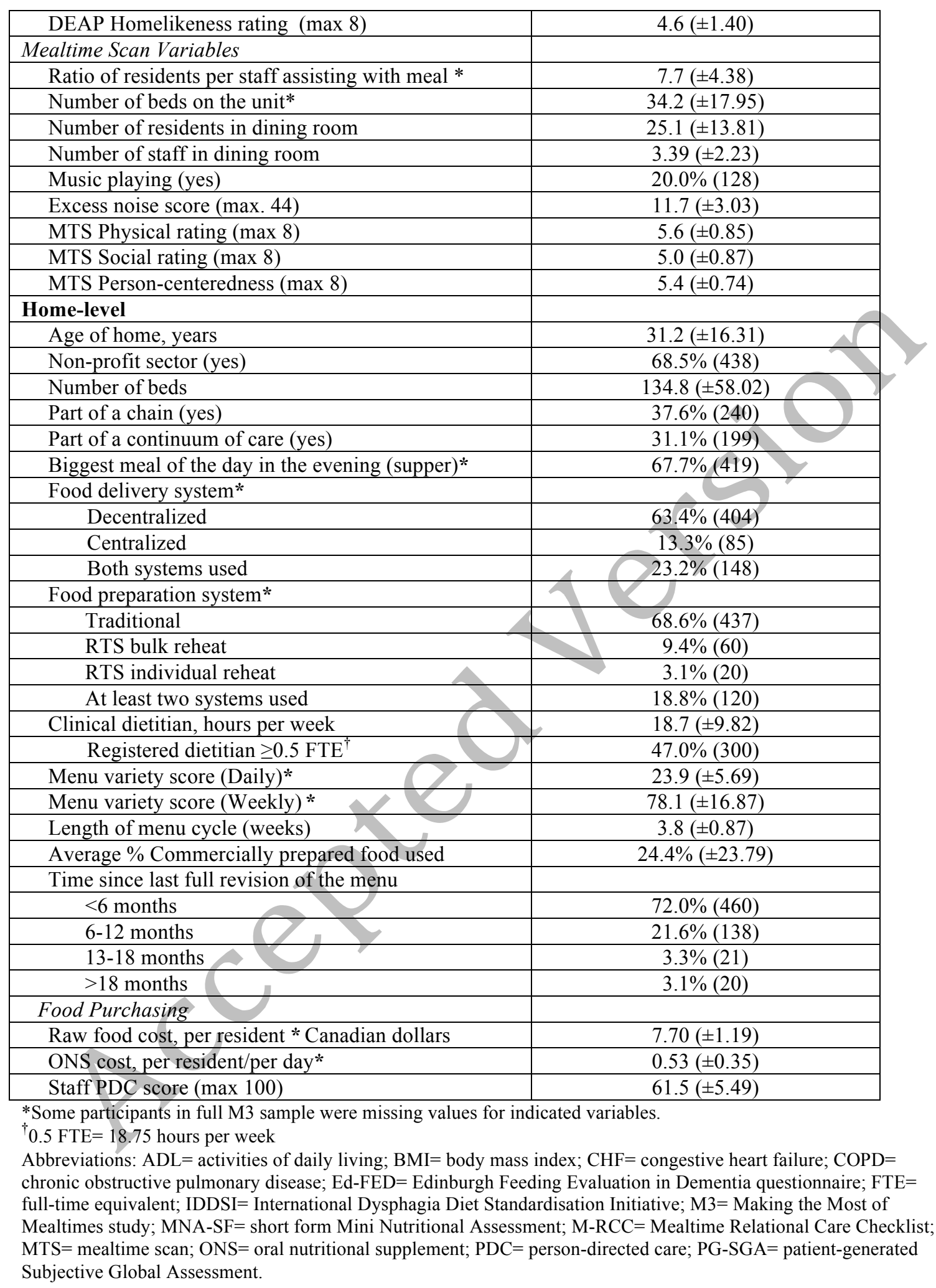


Table 2. Bivariate analyses with energy and protein intake, adjusted for nested levels, age and gender $(\mathrm{n}=628)$

\begin{tabular}{|c|c|c|c|c|}
\hline & \multicolumn{2}{|c|}{ Energy Intake } & \multicolumn{2}{|c|}{ Protein Intake } \\
\hline & $\begin{array}{l}\text { Parameter } \\
\text { Estimate }\end{array}$ & $\begin{array}{c}\mathrm{p}- \\
\text { value }\end{array}$ & $\begin{array}{l}\text { Parameter } \\
\text { Estimate }\end{array}$ & $\begin{array}{c}\mathrm{p}- \\
\text { value }\end{array}$ \\
\hline \multicolumn{5}{|l|}{ Resident-level } \\
\hline Age (yrs) & -11.07 & $<0.01$ & -0.48 & $<0.01$ \\
\hline Gender, male & 200.25 & $<0.01$ & 9.66 & $<0.01$ \\
\hline BMI* & 9.80 & $<0.01$ & 0.22 & 0.07 \\
\hline Malnutrition (PG-SGA; B or C rating)* & -197.32 & $<0.01$ & -5.96 & $<0.01$ \\
\hline MNA-SF Score & 34.11 & $<0.01$ & 1.06 & $<0.01$ \\
\hline Number of diagnoses & -12.09 & 0.14 & -0.50 & 0.15 \\
\hline COPD diagnosis & -38.29 & 0.36 & -2.02 & 0.25 \\
\hline Number of drugs prescribed & -3.44 & 0.49 & -0.28 & 0.18 \\
\hline $\begin{array}{l}\text { Moderate/Severe Cognitive impairment* (CPS } \\
3+\text { ) }\end{array}$ & -42.69 & 0.23 & -1.77 & 0.24 \\
\hline ADL score (InterRAI)* & -7.25 & $<0.01$ & -0.20 & 0.03 \\
\hline Physical help required during mealtime & & $<0.01$ & $y$ & $<0.01$ \\
\hline Never & $t$ & + & $\dagger$ & $\dagger$ \\
\hline Sometimes & -200.86 & $<0.01$ & -9.87 & $<0.01$ \\
\hline \multicolumn{5}{|l|}{ Often } \\
\hline Ed-FED score & -40.08 & $<0.01$ & -1.59 & $<0.01$ \\
\hline Other eating challenges score & -36.76 & $<0.01$ & -1.33 & $<0.01$ \\
\hline Average mealtime length & -2.01 & 0.21 & -0.09 & 0.16 \\
\hline Number of teeth* & -1.56 & 0.35 & -0.11 & 0.12 \\
\hline $\begin{array}{l}\text { Oral health status likely to affect food } \\
\text { intake* (yes) }\end{array}$ & -79.33 & 0.03 & -1.86 & 0.23 \\
\hline Urgent dental care required* (yes) & -43.22 & 0.46 & -3.03 & 0.22 \\
\hline Pureed/Liquidized (IDDSI) & 57.20 & 0.25 & 2.83 & $<0.01$ \\
\hline Thickened fluids (yes) & -12.76 & 0.80 & -2.44 & 0.25 \\
\hline Any diet prescription (yes) & -49.60 & 0.15 & -0.88 & 0.54 \\
\hline Cultural preferences met* (yes) & 24.60 & 0.64 & 2.79 & 0.21 \\
\hline ONS prescribed (yes) & -71.62 & 0.03 & -1.66 & 0.24 \\
\hline \multicolumn{5}{|l|}{ Unit-level } \\
\hline Living on a dementia care unit & 136.91 & 0.03 & 9.90 & 0.06 \\
\hline $\begin{array}{l}\text { Ratio of residents in dining room per staff } \\
\text { assisting with meal (MTS)* }\end{array}$ & -104.05 & 0.01 & -3.02 & 0.02 \\
\hline Number of residents in dining room (MTS) & 81.07 & 0.28 & 2.44 & 0.16 \\
\hline Number of staff in dining room (MTS) & 243.22 & 0.08 & 7.34 & 0.41 \\
\hline Excess noise score (max. 44m; MTS) & 60.80 & 0.11 & 1.83 & 0.34 \\
\hline DEAP Homelikeness rating & 293.98 & 0.03 & 7.92 & 0.12 \\
\hline MTS Person-centeredness rating & 881.93 & 0.08 & 23.75 & 0.16 \\
\hline \multicolumn{5}{|l|}{ Home-level } \\
\hline Number of beds in home & -1.51 & 0.42 & 0.04 & 0.09 \\
\hline $\begin{array}{l}\text { Biggest meal of the day in the evening } \\
\text { (supper)* }\end{array}$ & -137.33 & 0.90 & -23.44 & 0.01 \\
\hline Clinical dietitian, hours per week & -6.35 & 0.20 & 0.15 & 0.03 \\
\hline Registered dietitian $\geq 0.5 \mathrm{FTE}^{\S}$ & 653.91 & 0.41 & 8.81 & $<0.01$ \\
\hline Time since last full revision of the menu & & 0.02 & & 0.05 \\
\hline$<6$ months & $\dagger$ & $\dagger$ & $\dagger$ & $\dagger$ \\
\hline
\end{tabular}




\begin{tabular}{|c|c|c|c|c|}
\hline 6-12 months & -653.91 & 0.07 & -4.20 & 0.39 \\
\hline 13-18 months & -1821.25 & $<0.01$ & -18.39 & $<0.01$ \\
\hline$>18$ months & 156.54 & 0.66 & -16.72 & $<0.01$ \\
\hline Raw food cost/ resident, Canadian dollars* & 286.51 & 0.99 & -48.94 & 0.09 \\
\hline Staff PDC score & 33.11 & 0.09 & -0.79 & 0.10 \\
\hline
\end{tabular}

Note: only variables that were associated with energy or protein intake at $\mathrm{p}<0.25$, and therefore included in the respective backwards regression analysis, are presented.

*Participants were missing values for indicated variables; BMI, $\mathrm{n}=617$; pg-SGA, $\mathrm{n}=627$; cognitive impairment, $\mathrm{n}=623$; ADL score, $n=623$; number of teeth, $n=557$; oral health status, $n=561$; urgent dental care, $n=563$; resident $/$ staff ratio, $\mathrm{n}=558$; biggest meal, $\mathrm{n}=608$; cultural preferences met, $\mathrm{n}=623$; raw food cost, $\mathrm{n}=530$.

${ }^{\dagger}$ Referent category ${ }^{\S} 0.5 \mathrm{FTE}=18.75$ hours per week

Abbreviations: $\mathrm{ADL}=$ activities of daily living; $\mathrm{BMI}=$ body mass index $\mathrm{COPD}=$ chronic obstructive pulmonary disease; DEAP= Dining Environment Audit Protocol; Ed-FED= Edinburgh Feeding Evaluation in Dementia questionnaire; FTE = full-time equivalent; IDDSI= International Dysphagia Diet Standardisation Initiative; M3= Making the Most of Mealtimes study; MNA-SF= short form Mini Nutritional Assessment; MTS= mealtime scan; $\mathrm{ONS}=$ oral nutritional supplement; $\mathrm{PDC}=$ person-directed care; $\mathrm{PG}-\mathrm{SGA}=$ patient-generated Subjective Global Assessment. 
Table 3. Determinants of M3 resident energy and protein intake based on multivariate linear regression analysis $(\mathrm{n}=628)$

\begin{tabular}{|c|c|c|c|c|c|c|c|c|}
\hline & \multicolumn{4}{|c|}{ Energy Intake } & \multicolumn{4}{|c|}{ Protein Intake } \\
\hline & \multirow{2}{*}{\multicolumn{2}{|c|}{ Initial Model }} & \multirow{2}{*}{\multicolumn{2}{|c|}{$\begin{array}{c}\begin{array}{c}\text { Final Model with } \\
\text { Interaction Term }\end{array} \\
0.32 \\
\end{array}$}} & \multirow{2}{*}{\multicolumn{2}{|c|}{ Initial Model }} & \multirow{2}{*}{\multicolumn{2}{|c|}{$\begin{array}{l}\text { Final Model with } \\
\text { Interaction Term }\end{array}$}} \\
\hline Adjusted $\mathrm{R}^{2}$ & & & & & & & & \\
\hline Variable & $\begin{array}{l}\text { Parameter } \\
\text { Estimate }\end{array}$ & p-value & $\begin{array}{c}\text { Paramete } \\
\mathrm{r} \\
\text { Estimate }\end{array}$ & p-value & $\begin{array}{l}\text { Parameter } \\
\text { Estimate }\end{array}$ & p-value & $\begin{array}{c}\text { Parameter } \\
\text { Estimate }\end{array}$ & p-value \\
\hline \multicolumn{9}{|l|}{ Resident Level } \\
\hline Age, years & -8.88 & $<0.01$ & -9.04 & $<0.01$ & -0.39 & $<0.01$ & -0.39 & $<0.01$ \\
\hline Gender, male & 200.9 & $<0.01$ & 202.67 & $<0.01$ & 9.54 & $<0.01$ & 9.57 & $<0.01$ \\
\hline Ed-FED score & -56.48 & $<0.01$ & -63.37 & $<0.01$ & -3.01 & $<0.01$ & -3.14 & $<0.01$ \\
\hline $\begin{array}{l}\text { Pureed/liquidized } \\
\text { diet }\end{array}$ & 160.35 & $<0.01$ & -418.07 & 0.15 & 9.07 & $<0.01$ & -1.66 & 0.89 \\
\hline MNA-SF score & 25.35 & $<0.01$ & 24.45 & $<0.01$ & 0.67 & 0.02 & 0.65 & 0.02 \\
\hline $\begin{array}{l}\text { Physical assistance } \\
\text { received at } \\
\text { mealtimes }\end{array}$ & & $<0.01$ & & 0.02 & & $<0.01$ & & $<0.01$ \\
\hline Never/rarely & $*$ & & $*$ & & * & & $*$ & \\
\hline Sometimes & -14.88 & & -2.16 & r & -1.11 & & -0.87 & \\
\hline Often & 213.76 & & 192.17 & & 12.74 & & 12.34 & \\
\hline \multicolumn{9}{|l|}{ Unit Level } \\
\hline Homelikeness score & -1.60 & 0.02 & -20.23 & 0.02 & -- & -- & -- & -- \\
\hline $\begin{array}{l}\text { Person-centered } \\
\text { score }\end{array}$ & 236.33 & 0.03 & 306.88 & 0.04 & -- & -- & -- & -- \\
\hline Dementia care unit & 136.67 & $<0.01$ & 148.45 & $<0.01$ & 4.06 & $<0.01$ & 4.28 & $<0.01$ \\
\hline \multicolumn{9}{|l|}{ Home Level } \\
\hline $\mathrm{RD} \geq 0.5 \mathrm{FTE}^{\dagger}$ & -- & & -- & -- & 3.35 & 0.01 & 3.41 & 0.01 \\
\hline \multicolumn{9}{|l|}{ Interaction Term } \\
\hline $\begin{array}{l}\text { Ed-FED } \\
\text { diet }\end{array}$ & & & 39.93 & 0.04 & -- & -- & 0.74 & 0.36 \\
\hline
\end{tabular}

* Referent category

$\dagger 0.5 \mathrm{FTE}=18.75$ hours/week

Raw models compared to model with interaction between Ed-FED and pureed/liquidized diet prescription.

Abbreviations: Ed-FED= Edinburgh Feeding Evaluation in Dementia questionnaire; FTE= Full time equivalent; MNA-

$\mathrm{SF}=$ short form Mini Nutritional Assessment; $\mathrm{RD}=$ registered dietitian. 
Supplementary Table 1. Description of resident-level factors in the M3 sample and bivariate analysis of the association between each factor and food intake.

\begin{tabular}{|c|c|c|c|c|c|c|c|}
\hline \multirow[b]{2}{*}{ Variable of interest } & $\begin{array}{l}\text { Sam } \\
\text { Full M3 } \\
\text { Sample } \\
(\mathrm{n}=639)\end{array}$ & $\begin{array}{r}\text { Descr } \\
\text { Sam } \\
\mathrm{M} \\
\end{array}$ & $\begin{array}{l}\text { tion } \\
\text { le Used in } \\
\text { ltivariate } \\
\text { nalysis } \\
n=628)\end{array}$ & Energ & ivariat & 1alyses* & \\
\hline & $\begin{array}{c}\text { Mean } \\
(\mathrm{SD}) / \\
\text { Frequency } \\
\text { (n) }\end{array}$ & $\mathrm{N}$ & $\begin{array}{c}\text { Mean } \\
(\mathrm{SD}) / \\
\text { Frequency } \\
\text { (n) }\end{array}$ & $\begin{array}{c}\text { Parameter } \\
\text { Estimate }\end{array}$ & $\begin{array}{c}\mathrm{p}- \\
\text { value }\end{array}$ & $\begin{array}{l}\text { Parameter } \\
\text { Estimate }\end{array}$ & $\begin{array}{c}\mathrm{p}- \\
\text { value }\end{array}$ \\
\hline \multicolumn{8}{|l|}{ Outcomes } \\
\hline Energy Intake, kcal/day & $\begin{array}{c}1571.9 \\
( \pm 411.93)\end{array}$ & 628 & $\begin{array}{c}1582.1 \\
( \pm 400.46)\end{array}$ & & -- & -- & -- \\
\hline Protein Intake, g/day & $\begin{array}{c}58.4 \\
( \pm 18.02)\end{array}$ & 628 & $\begin{array}{c}58.7 \\
( \pm 17.59)\end{array}$ & & -- & -- & -- \\
\hline $\begin{array}{l}\leq 0.8 \text { g protein } / \mathrm{kg} \\
\text { bodyweight }\end{array}$ & $\begin{array}{c}41.6 \% \\
(266)\end{array}$ & 628 & $\begin{array}{l}40.8 \% \\
(256)\end{array}$ & -- & -- & -- & -- \\
\hline \multicolumn{8}{|l|}{ Resident Demographics } \\
\hline Age & $\begin{array}{c}86.8 \\
( \pm 7.83)\end{array}$ & & $( \pm 7.82)$ & -11.07 & $<0.01$ & -0.48 & $<0.01$ \\
\hline Gender, male & $\begin{array}{l}31.1 \% \\
(199)\end{array}$ & & $\begin{array}{l}31.2 \% \\
(196)\end{array}$ & 200.25 & $<0.01$ & 9.66 & $<0.01$ \\
\hline \multicolumn{8}{|c|}{ Body Composition \& Nutritional Status } \\
\hline $\mathrm{BMI}^{\dagger}$ & & 617 & $\begin{array}{c}25.4 \\
( \pm 5.75)\end{array}$ & 9.80 & $<0.01$ & 0.22 & 0.07 \\
\hline $\begin{array}{l}\text { Malnutrition (PG-SGA; B } \\
\text { or C rating) }\end{array}$ & $\begin{array}{l}44.0 \% \\
(281)\end{array}$ & 627 & $\begin{array}{l}43.7 \% \\
(274)\end{array}$ & -197.32 & $<0.01$ & -5.96 & $<\mathbf{0 . 0 1}$ \\
\hline MNA-SF Score $^{\dagger}$ & $\begin{array}{c}10.6 \\
( \pm 2.53)\end{array}$ & 628 & $\begin{array}{c}10.7 \\
( \pm 2.49)\end{array}$ & 34.11 & $<0.01$ & 1.06 & $<0.01$ \\
\hline \multicolumn{8}{|c|}{ Diagnoses, Prescriptions \& Pain } \\
\hline $\mathrm{CHF}^{\dagger}$ & $\begin{array}{l}12.8 \% \\
(82)\end{array}$ & 627 & $\begin{array}{l}12.9 \% \\
(81)\end{array}$ & -1.61 & 0.97 & 1.13 & 0.56 \\
\hline COPD & $\begin{array}{c}15.3 \% \\
(98)\end{array}$ & 628 & $\begin{array}{c}15.4 \% \\
(97)\end{array}$ & -38.29 & 0.36 & -2.02 & 0.25 \\
\hline Current cancer ${ }^{\dagger}$ & $\begin{array}{l}15.0 \% \\
(96)\end{array}$ & 627 & $\begin{array}{l}15.3 \% \\
(96)\end{array}$ & 41.91 & 0.32 & 1.37 & 0.44 \\
\hline Dementia & $\begin{array}{l}65.0 \% \\
(416)\end{array}$ & 628 & $\begin{array}{l}65.3 \% \\
(410)\end{array}$ & 27.38 & 0.43 & 0.10 & 0.94 \\
\hline Depression $^{\dagger}$ & $\begin{array}{l}31.5 \% \\
(201)\end{array}$ & 627 & $\begin{array}{l}30.8 \% \\
(193)\end{array}$ & -2.23 & 0.95 & -0.67 & 0.64 \\
\hline Depression Scale (MDS) ${ }^{\dagger}$ & $\begin{array}{c}2.3 \\
( \pm 2.92)\end{array}$ & 623 & $\begin{array}{c}2.3 \\
( \pm 2.91)\end{array}$ & 0.50 & 0.94 & -0.01 & 0.97 \\
\hline
\end{tabular}




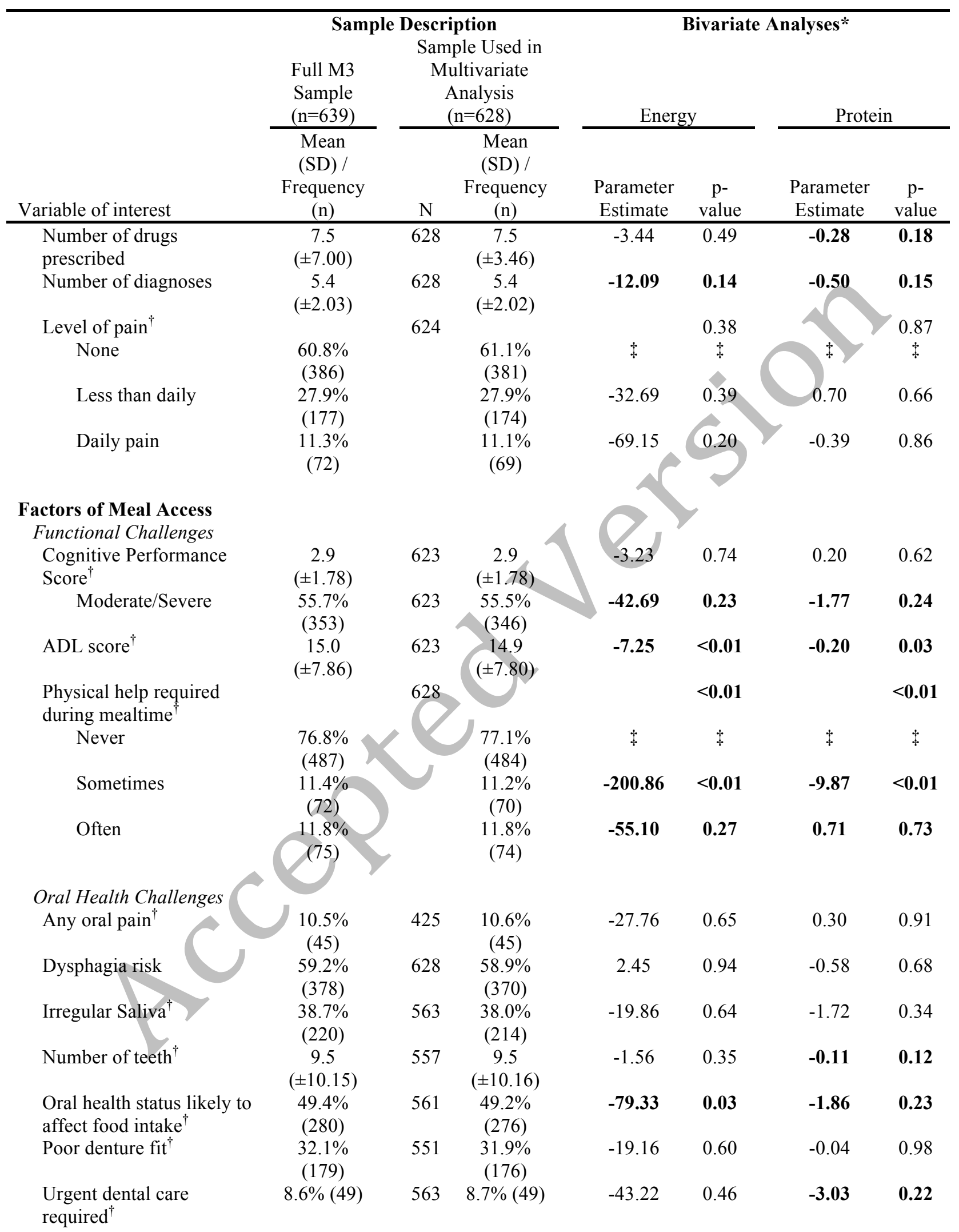

Factors of Meal Quality 


\begin{tabular}{|c|c|c|c|c|c|c|c|}
\hline \multirow[b]{3}{*}{ Variable of interest } & \multicolumn{3}{|c|}{ Sample Description } & \multicolumn{4}{|c|}{ Bivariate Analyses* } \\
\hline & $\begin{array}{l}\text { Full M3 } \\
\text { Sample } \\
(\mathrm{n}=639) \\
\end{array}$ & $\begin{array}{r}\text { Sam } \\
\mathrm{M} \\
\\
\end{array}$ & $\begin{array}{l}\text { le Used in } \\
\text { ltivariate } \\
\text { nalysis } \\
n=628)\end{array}$ & \multicolumn{2}{|c|}{ Energy } & \multicolumn{2}{|c|}{ Protein } \\
\hline & $\begin{array}{c}\text { Mean } \\
(\mathrm{SD}) / \\
\text { Frequency } \\
\text { (n) }\end{array}$ & $\mathrm{N}$ & $\begin{array}{c}\text { Mean } \\
(\mathrm{SD}) / \\
\text { Frequency } \\
(\mathrm{n})\end{array}$ & $\begin{array}{c}\text { Parameter } \\
\text { Estimate }\end{array}$ & $\begin{array}{c}\mathrm{p}- \\
\text { value }\end{array}$ & $\begin{array}{c}\text { Parameter } \\
\text { Estimate }\end{array}$ & $\begin{array}{c}\mathrm{p}- \\
\text { value }\end{array}$ \\
\hline \multicolumn{8}{|l|}{ Modified Textures } \\
\hline Modified texture (IDDSI) & $\begin{array}{c}47.1 \% \\
(301)\end{array}$ & 628 & $\begin{array}{c}47.1 \% \\
(296)\end{array}$ & -10.32 & 0.74 & 0.30 & 0.82 \\
\hline $\begin{array}{l}\text { Pureed/Liquidized } \\
\text { (IDDSI) }\end{array}$ & $\begin{array}{l}11.1 \% \\
(71)\end{array}$ & 628 & $\begin{array}{c}11.2 \% \\
(70)\end{array}$ & 57.20 & 0.25 & 2.83 & $<0.01$ \\
\hline Thickened fluids & $\begin{array}{c}10.6 \% \\
(68)\end{array}$ & 628 & $\begin{array}{l}10.7 \% \\
(67)\end{array}$ & -12.76 & 0.80 & & 0.25 \\
\hline \multicolumn{8}{|l|}{$\begin{array}{l}\text { Specialized Diets \& } \\
\text { Supplementation }\end{array}$} \\
\hline Any diet prescription & $\begin{array}{l}37.7 \% \\
(241)\end{array}$ & 628 & $\begin{array}{l}37.9 \% \\
(238)\end{array}$ & -49.60 & 0.15 & -0.88 & 0.54 \\
\hline Cultural preferences met & $\begin{array}{l}70.4 \% \\
(446)\end{array}$ & 623 & $\begin{array}{l}70.5 \% \\
(439)\end{array}$ & & 0.64 & 2.79 & 0.21 \\
\hline ONS prescribed & $\begin{array}{c}30.7 \% \\
(196)\end{array}$ & 628 & $\begin{array}{c}30.6 \% \\
(192)\end{array}$ & -71.62 & 0.03 & -1.66 & -0.24 \\
\hline \multicolumn{8}{|l|}{ Factors of Mealtime } \\
\hline \multicolumn{8}{|l|}{ Experience } \\
\hline Ed-FED-q score ${ }^{\dagger}$ & $\begin{array}{c}12.4 \\
( \pm 2.25)\end{array}$ & & 12.4 & -40.08 & $<0.01$ & -1.59 & $<0.01$ \\
\hline $\begin{array}{l}\text { Other eating challenges } \\
\text { score }^{\dagger}\end{array}$ & $\begin{array}{c}10.6 \\
( \pm 1.65)\end{array}$ & & $\begin{array}{c}10.6 \\
( \pm 1.65)\end{array}$ & -36.76 & $<0.01$ & -1.33 & $<0.01$ \\
\hline $\begin{array}{l}\text { All eating challenges } \\
\text { score }^{\dagger}\end{array}$ & $\begin{array}{c}23.0 \\
( \pm 3.68)\end{array}$ & 628 & $\begin{array}{c}23.0 \\
( \pm 3.66)\end{array}$ & -22.89 & $<0.01$ & -0.88 & $<0.01$ \\
\hline \multicolumn{8}{|l|}{ Relational Care } \\
\hline Average mealtime length ${ }^{\dagger}$ & $\begin{array}{c}40.2 \\
( \pm 13.04)\end{array}$ & 628 & $\begin{array}{c}40.3 \\
( \pm 12.98)\end{array}$ & -2.01 & 0.21 & -0.09 & 0.16 \\
\hline $\begin{array}{l}\text { Proportion of negative } \\
\text { MRCC events }\end{array}$ & $\begin{array}{c}36.6 \\
( \pm 11.23)\end{array}$ & 628 & $\begin{array}{c}36.6 \\
( \pm 11.24)\end{array}$ & 1.21 & 0.27 & 0.06 & 0.80 \\
\hline $\begin{array}{l}\text { Proportion of Positive } \\
\text { MRCC events }\end{array}$ & $\begin{array}{c}63.4 \\
( \pm 11.23)\end{array}$ & 628 & $\begin{array}{c}63.4 \\
( \pm 11.24)\end{array}$ & 1.21 & 0.27 & 0.06 & 0.80 \\
\hline $\begin{array}{l}\text { Positive:Negative MRCC } \\
\text { Score }^{\dagger}\end{array}$ & $\begin{array}{c}2.2 \\
( \pm 1.32)\end{array}$ & 628 & $\begin{array}{c}2.2 \\
( \pm 1.29)\end{array}$ & 1.58 & 0.92 & -0.61 & 0.34 \\
\hline
\end{tabular}

Bolded values indicate variables that were included in the multivariate backwards regression analysis given $\mathbf{p} \leq \mathbf{0 . 2 5}$

*Bivariate analysis of energy or protein intake as the dependent variable regressed on specified variable, controlled for nested levels, age and gender

${ }^{\dagger}$ Some participants in full M3 sample were missing values for indicated variables: CHF, current cancer \& depression diagnoses, Malnutrition (PG-SGA, rating B and C) and malnutrition risk scores (MNA-SF), n=638; Average mealtime length, $n=637$; Level of pain, $n=635$; Depression scale (MDS), ADL score, Cognitive performance score, Mealtime observation scores (Physical help required, Ed-FED-q, Other/all eating challenges, Positive and negative MRCC scores), $\mathrm{n}=634$; BMI, $\mathrm{n}=626$; Irregular saliva, Urgent dental care required; Oral health status likely to affect food intake, $\mathrm{n}=567$; Number of teeth, $n=563$; Poor denture fit, $n=557$; Any oral pain, $n=428$. 
${ }^{\ddagger}$ Referent category

Abbreviations: $\mathrm{ADL}=$ activities of daily living; $\mathrm{BMI}=$ body mass index; $\mathrm{CHF}=$ congestive heart failure; $\mathrm{COPD}=\mathrm{chronic}$ obstructive pulmonary disease; Ed-FED-q= Edinburgh Feeding Evaluation in Dementia questionnaire; IDDSI= International Dysphagia Diet Standardisation Initiative; M3= Making the Most of Mealtimes project; MDS= Minimum Data Set; MNA-SF= short form Mini Nutritional Assessment; MRCC $=$ Mealtime Relational Care Checklist; ONS $=$ oral nutritional supplement; PG-SGA= patient-generated Subjective Global Assessment.

Supplementary Table 2. Description of unit-level factors in the M3 sample and bivariate analysis of the association between each factor and food intake.

\begin{tabular}{|c|c|c|c|c|c|c|c|}
\hline & \multicolumn{3}{|c|}{ Sample Description } & \multicolumn{4}{|c|}{ Bivariate Analyses* } \\
\hline & \multirow{2}{*}{ 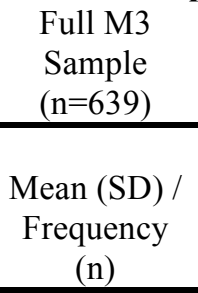 } & \multicolumn{2}{|c|}{$\begin{array}{c}\text { Sample Used in } \\
\text { Multivariate } \\
\text { Analysis }(n=628)\end{array}$} & \multicolumn{2}{|c|}{ Energy } & \multicolumn{2}{|c|}{ Protein } \\
\hline & & $\mathrm{N}$ & $\begin{array}{l}\text { Mean (SD) / } \\
\text { Frequency } \\
\text { (n) }\end{array}$ & $\begin{array}{c}\text { er } \\
\text { Estimat } \\
\mathrm{e}\end{array}$ & $\begin{array}{l}\mathrm{p}- \\
\text { value }\end{array}$ & $\begin{array}{l}\text { eter } \\
\text { Estima } \\
\text { te }\end{array}$ & $\begin{array}{c}\mathrm{p}- \\
\text { valu } \\
\mathrm{e}\end{array}$ \\
\hline \multicolumn{8}{|l|}{ Unit Demographics } \\
\hline Segregated unit & $28.8 \%(184)$ & 628 & $29.0 \%(182)$ & 136.91 & 0.03 & 9.90 & 0.06 \\
\hline $\begin{array}{l}\text { Renovations to unit in past } \\
5 \text { years }^{\dagger}\end{array}$ & $20.2 \%(127)$ & 618 & $20.6 \%(127)$ & -406.37 & 0.86 & -4.61 & 0.39 \\
\hline \multicolumn{8}{|l|}{ Factors of Meal Access } \\
\hline $\begin{array}{l}\text { Functionality of dining } \\
\text { room }\end{array}$ & $5.3( \pm 1.03)$ & & $5.3( \pm 1.02)$ & -121.61 & 0.96 & -3.67 & 0.95 \\
\hline $\begin{array}{l}\text { Residents per staff assisting } \\
\text { with meal }\end{array}$ & $7.7( \pm 4.38)$ & & $7.7( \pm 4.38)$ & -104.05 & 0.01 & -3.02 & 0.02 \\
\hline \multicolumn{8}{|l|}{ Factors of Mealtime } \\
\hline \multicolumn{7}{|l|}{ Experience } & \\
\hline Number of beds on the unit ${ }^{\dagger}$ & & 608 & $\begin{array}{c}34.1 \\
( \pm 17.87)\end{array}$ & -1.54 & 0.96 & -0.05 & 0.68 \\
\hline $\begin{array}{l}\text { Number of residents in } \\
\text { dining room }\end{array}$ & $( \pm 13.81)$ & 628 & $\begin{array}{c}25.1 \\
( \pm 13.86)\end{array}$ & 81.07 & 0.28 & 2.44 & 0.16 \\
\hline $\begin{array}{l}\text { Number of staff in dining } \\
\text { room }\end{array}$ & $3.39( \pm 2.23)$ & 628 & $3.4( \pm 2.24)$ & 243.22 & 0.08 & 7.34 & 0.41 \\
\hline Excess noise score & $11.7( \pm 3.03)$ & 628 & $11.7( \pm 3.00)$ & 60.80 & 0.11 & 1.83 & 0.34 \\
\hline Music playing & $20.0 \%(128)$ & 628 & $20.1 \%(126)$ & -97.54 & 0.72 & -9.14 & 0.75 \\
\hline \multicolumn{8}{|l|}{ Summary Scores } \\
\hline Homelikeness rating & $4.6( \pm 1.40)$ & 628 & $4.6( \pm 1.40)$ & 293.98 & 0.03 & 7.92 & 0.12 \\
\hline Physical rating & $5.6( \pm 0.85)$ & 628 & $5.6( \pm 0.84)$ & -162.15 & 0.33 & -4.89 & 0.27 \\
\hline Social rating & $5.0( \pm 0.87)$ & 628 & $5.0( \pm 0.86)$ & 486.45 & 0.57 & 14.67 & 0.90 \\
\hline Person-centredness & $5.4( \pm 0.74)$ & 628 & $5.4( \pm 0.73)$ & 881.93 & 0.08 & 23.75 & 0.16 \\
\hline
\end{tabular}

Bolded values indicate variables that were included in the multivariate backwards regression analysis given $\mathbf{p} \leq 0.25$ *Bivariate analysis of energy or protein intake as the dependent variable regressed on specified variable, controlled for nested levels, age and gender; the unexplained variation between units within LTC homes was used as the error term for unit-level variables.

${ }^{\dagger}$ Some participants in full M3 sample were missing values for indicated unit-level variables: Renovations to unit in past 5 years, $\mathrm{n}=629$; Number of beds on the unit, $\mathrm{n}=619$; Residents per staff assisting at meal, $\mathrm{n}=569$. 
Abbreviations: $\mathrm{LTC}=$ long-term care; M3= Making the Most of Mealtimes project.

Supplementary Table 3. Description of LTC home-level factors in the M3 sample and bivariate analysis of the association between each factor and food intake.

\begin{tabular}{|c|c|c|c|c|c|c|c|}
\hline & \multicolumn{3}{|c|}{ Sample Description } & \multicolumn{4}{|c|}{ Bivariate Analyses* } \\
\hline & \multirow{2}{*}{$\begin{array}{c}\text { Full M3 } \\
\text { Sample } \\
(\mathrm{n}=639) \\
\text { Mean (SD) } \\
/ \\
\text { Frequency } \\
(\mathrm{n})\end{array}$} & \multicolumn{2}{|c|}{$\begin{array}{l}\text { Sample Used in } \\
\text { Multivariate } \\
\text { Analysis }(\mathrm{n}=628)\end{array}$} & \multicolumn{2}{|c|}{ Energy } & \multicolumn{2}{|c|}{ Protein } \\
\hline & & $\mathrm{N}$ & $\begin{array}{c}\text { Mean } \\
(\mathrm{SD}) / \\
\text { Frequenc } \\
\mathrm{y}(\mathrm{n})\end{array}$ & $\begin{array}{c}\begin{array}{c}\text { Parame } \\
\text { ter } \\
\text { Estimat } \\
\mathrm{e}\end{array} \\
\end{array}$ & $\begin{array}{c}\mathrm{p}- \\
\text { value }\end{array}$ & $\begin{array}{l}\text { Param } \\
\text { eter } \\
\text { Estima } \\
\text { te }\end{array}$ & $\begin{array}{c}\mathrm{p}- \\
\text { valu } \\
\mathrm{e}\end{array}$ \\
\hline Home Demographics & & & & $\bar{a}=$ & & & \\
\hline Age of home, years & $\begin{array}{c}31.2 \\
( \pm 16.31)\end{array}$ & 628 & $\begin{array}{c}31.1 \\
( \pm 16.36)\end{array}$ & -3.95 & 0.46 & -0.51 & 0.76 \\
\hline Non-profit sector & $\begin{array}{c}68.5 \% \\
(438)\end{array}$ & 628 & $\begin{array}{l}68.8 \% \\
(432)\end{array}$ & 653.91 & 0.91 & 4.19 & 0.87 \\
\hline Number of beds & $\begin{array}{c}134.8 \\
( \pm 58.02)\end{array}$ & 628 & $\begin{array}{c}135.4 \\
( \pm 58.15)\end{array}$ & -1.51 & 0.42 & 0.04 & 0.09 \\
\hline Part of a chain & $\begin{array}{l}37.6 \% \\
(240)\end{array}$ & & $\begin{array}{l}37.7 \% \\
(237)\end{array}$ & -653.91 & 0.62 & -4.19 & 0.32 \\
\hline Part of a continuum of care & $\begin{array}{l}31.1 \% \\
(199)\end{array}$ & & $\begin{array}{l}31.4 \% \\
(197)\end{array}$ & 653.91 & 0.84 & 4.19 & 0.81 \\
\hline \multicolumn{8}{|l|}{ Factors of Meal Access } \\
\hline $\begin{array}{l}\text { Biggest meal of the day in the } \\
\text { evening (supper) }\end{array}$ & $\begin{array}{l}67.7 \% \\
(419)\end{array}$ & 608 & $\begin{array}{l}67.8 \% \\
(412)\end{array}$ & -137.33 & 0.90 & -23.44 & 0.01 \\
\hline Food delivery system ${ }^{\dagger}$ & & 626 & & & 0.42 & & 0.54 \\
\hline Decentralized & & & $\begin{array}{l}63.6 \% \\
(398)\end{array}$ & 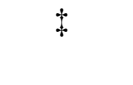 & $\$$ & $\$$ & + \\
\hline Centralized & $3.3 \%(85)$ & & $\begin{array}{c}13.6 \% \\
(85)\end{array}$ & -71.52 & 0.79 & -5.44 & 0.30 \\
\hline Both systems used & $\begin{array}{c}23.2 \% \\
(148)\end{array}$ & & $\begin{array}{l}22.8 \% \\
(143)\end{array}$ & -107.60 & 0.79 & 0.22 & 0.98 \\
\hline Food preparation system ${ }^{\dagger}$ & & 626 & & & 0.85 & & 0.90 \\
\hline Traditional & $\begin{array}{c}68.6 \% \\
(437)\end{array}$ & & $\begin{array}{c}69.0 \% \\
(432)\end{array}$ & $\ddagger$ & $\$$ & $\$$ & $\$$ \\
\hline RTS bulk reheat & $9.4 \%(60)$ & & $9.6 \%(60)$ & 430.76 & 0.23 & -4.32 & 0.38 \\
\hline RTS individual reheat & $3.1 \%(20)$ & & $3.2 \%(20)$ & -351.04 & 0.43 & 1.30 & 0.85 \\
\hline $\begin{array}{l}\text { At least two systems } \\
\text { used }\end{array}$ & $\begin{array}{l}18.8 \% \\
(120)\end{array}$ & & $\begin{array}{l}18.2 \% \\
(114)\end{array}$ & 156.80 & 0.66 & -16.69 & $\begin{array}{c}<0.0 \\
1\end{array}$ \\
\hline \multicolumn{8}{|l|}{$\begin{array}{l}\text { Factors of Meal Quality } \\
\text { Menu Planning }\end{array}$} \\
\hline $\begin{array}{l}\text { Clinical dietitian, hours per } \\
\text { week }\end{array}$ & $\begin{array}{c}18.7 \\
( \pm 9.82)\end{array}$ & 629 & $\begin{array}{c}18.8 \\
( \pm 9.77)\end{array}$ & -6.35 & 0.20 & 0.15 & 0.03 \\
\hline $\begin{array}{l}\text { Clinical dietitian } \geq 0.5 \\
\text { FTE }^{\S}\end{array}$ & $\begin{array}{l}47.0 \% \\
(300)\end{array}$ & 628 & $\begin{array}{l}47.3 \% \\
(297)\end{array}$ & 653.91 & 0.41 & 8.81 & $\begin{array}{c}<0.0 \\
1\end{array}$ \\
\hline
\end{tabular}




\begin{tabular}{|c|c|c|c|c|c|c|c|}
\hline Menu variety (Daily) ${ }^{\dagger}$ & $\begin{array}{c}23.9 \\
( \pm 5.69)\end{array}$ & 569 & $\begin{array}{c}24.0 \\
( \pm 5.69)\end{array}$ & -45.37 & 0.74 & 1.02 & 0.95 \\
\hline Menu variety (Weekly) ${ }^{\dagger}$ & $\begin{array}{c}78.1 \\
( \pm 16.87)\end{array}$ & 569 & $\begin{array}{c}78.2 \\
( \pm 16.84)\end{array}$ & 45.37 & 0.99 & -1.02 & 0.88 \\
\hline Length of menu cycle, weeks & $3.8( \pm 0.87)$ & 628 & $\begin{array}{c}3.8 \\
( \pm 0.87)\end{array}$ & 177.74 & 0.80 & -0.87 & 0.38 \\
\hline $\begin{array}{l}\text { Proportion of commercially } \\
\text { prepared food }\end{array}$ & $\begin{array}{c}24.4 \\
( \pm 23.79)\end{array}$ & 628 & $\begin{array}{c}24.5 \\
( \pm 23.93)\end{array}$ & 5.45 & 0.78 & -0.94 & 0.61 \\
\hline $\begin{array}{l}\text { Time since last full revision } \\
\text { of the menu }\end{array}$ & & 628 & & & 0.02 & & 0.05 \\
\hline$<6$ months & $\begin{array}{l}72.0 \% \\
(460)\end{array}$ & & $\begin{array}{l}72.4 \% \\
(455)\end{array}$ & 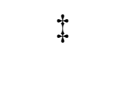 & $\$$ & $\ddagger$ & $\dagger$ \\
\hline 6-12 months & $\begin{array}{c}21.6 \% \\
(138)\end{array}$ & & $\begin{array}{l}21.5 \% \\
(135)\end{array}$ & -653.91 & 0.07 & -4.20 & 0.39 \\
\hline 13-18 months & $3.3 \%(21)$ & & $3.3 \%(21)$ & $\begin{array}{c}- \\
1821.2 \\
5\end{array}$ & & -18.39 & $\begin{array}{c}<0.0 \\
1\end{array}$ \\
\hline$>18$ months & $3.1 \%(20)$ & & $2.7 \%(17)$ & & & -16.72 & $\begin{array}{c}<0.0 \\
1\end{array}$ \\
\hline \multicolumn{8}{|l|}{ Food Purchasing } \\
\hline Raw food $\operatorname{cost}^{\dagger}$ & $\begin{array}{c}7.70 \\
( \pm 1.19)\end{array}$ & 530 & $\begin{array}{c}7.70 \\
( \pm 1.20)\end{array}$ & 286.51 & 1.00 & -48.94 & 0.09 \\
\hline ONS $\operatorname{cost}^{\dagger}$ & $\begin{array}{c}0.53 \\
( \pm 0.35)\end{array}$ & 530 & $\begin{array}{c}0.53 \\
( \pm 0.35)\end{array}$ & -239.30 & 0.65 & 41.97 & 0.49 \\
\hline \multicolumn{8}{|l|}{$\begin{array}{l}\text { actors of Mealtime } \\
\text { Experience }\end{array}$} \\
\hline Staff PDC score & $\begin{array}{c}61.5 \\
( \pm 5.49)\end{array}$ & & $\begin{array}{c}61.5 \\
( \pm 5.50)\end{array}$ & 33.11 & 0.09 & -0.79 & 0.10 \\
\hline
\end{tabular}

Bolded values indicate variables that were included in the multivariate backwards regression analysis given $p \leq 0.25$

*Bivariate analysis of energy or protein intake as the dependent variable regressed on specified variable, controlled for nested levels, age and gender; the unexplained variation between LTC homes within provinces was used as the error term for home-level variables.

${ }^{\dagger}$ Some participants in the full M3 sample were missing values for indicated variables: Food delivery \& Food preparation systems, $n=637$; Biggest meal of the day in evening, $n=619$; Menu variety scores (daily and weekly), $\mathrm{n}=579$; Raw food \& ONS costs, $\mathrm{n}=539$.

${ }^{*}$ Referent category

$\S_{0.5 \mathrm{FTE}}=18.75$ hours per week

Abbreviations: $\mathrm{LTC}=$ long-term care; $\mathrm{M} 3=$ Making the Most of Mealtimes project; ONS $=$ oral nutritional supplement; $\mathrm{PDC}=$ person-directed care; $\mathrm{RTS}=$ ready-to-serve. 


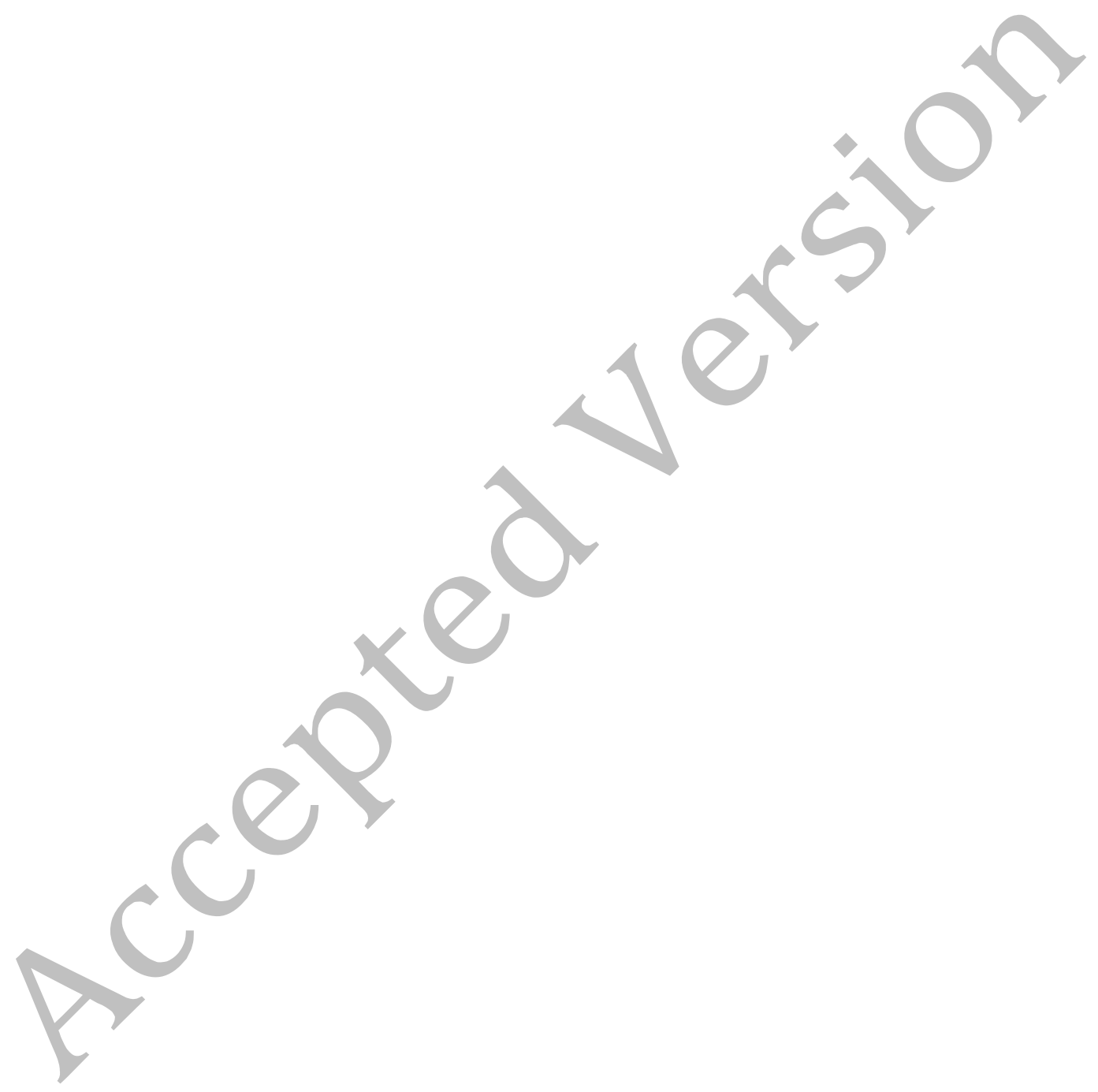

